А. В. Курицын [A. V. Kuritsyn]

A. Ю. Румянцева [A. Yu. Rumyantseva]

H. А. Лазарева [N. A. Lazareva]

\title{
СИСТЕМНЫЙ ПОДХОД К ОЦЕНКЕ ОРГАНИЗАЦИОННОЙ СЛОЖНОСТИ ИНДЕКСА СТОИМОСТИ
}

\section{SYSTEM APPROACH TO THE ESTIMATION OF THE ORGANIZATIONAL COMPLEXITY OF THE COST INDEX}

${ }^{1}$ ФГБФУ ВО «РГЭУ (РИНХ)», в г. Георгиевске Ставропольского края, Россия, e-mail: filialrgeu@yandex.ru.

${ }^{2}$ Институт международных программ, г. Санкт-Петербург, Россия, e-mail: post_graduate@mail.ru. ${ }^{3}$ Санкт-Петербургского университета технологий управления и экономики, Россия, e-mail: lazarev.1972@mail.ru

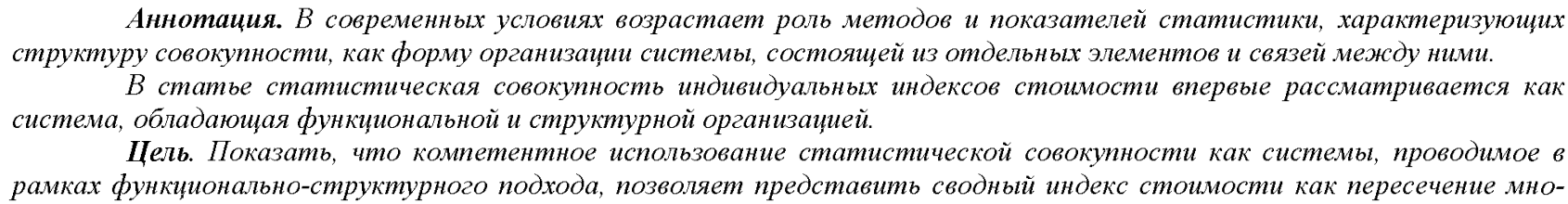
жеств функиионального и структурного атрибутов.

Задачи. Для достижения поставленной иели бьли реиень следующие задачи: выделень функциональньй и структурный элементы совокупности; сводный индекс стоимости представлен в виде структурной формульі; установлен принцип жёсткой детерминированной пропорциональности межоу функциональньм и структурньм атрибутами; обоснован выбор расчёта средних значений функционального и структурного атрибута.

Материалы и методы. В работе использовались традиционные методы математического анализа лножеств, статистические методь, методы исследования операций, обобцения, систематизации статистических данных, методьи меории принятия ремений.

Результать и обсуждения. Локазано, чмо без учёта структурной составляющей собственная суцность сводно2о индекса стоимости познана быль не может. Обоснована возможность комплексной оценки функииональной и структурной организации совокупности индексов стоимости как таковой. Показано, что организация совокулности будет соответствовать состоянию Парето - оптимальности при равенстве оценок функииональной и структурной составляюuyux.

Выводы. Чем ближе фактическая оценка организационной сложности совокупности к состоянию Парето - оптимальности, тел гармоничнее, совериеннее организация совокупности, тем качественно однороднее сала совокупность и возможиости её интерпретации в практических иелях.

Клочевье слова: индекс доли, коэффициент изменения структуры, многообразие элементной базы, функциональная и структурная организация, групповые и межгрупповые связи, Парето-оптимальность.

Abstracts. In modern conditions, the role of statistical methods and indicators that characterize the structure of a summation as a form of organization of a system consisting of individual elements and links between them is increasing.

In the article, the statistical set of individual cost indices is considered for the first time as a system that has a functional and structural organization.

Goal. To show that the competent use of the statistical summation as a system, carried out within the framework of the functional-structural approach, allows us to present the composite cost index as the intersection of sets of functional and structural attributes.

Tasks. To achieve this goal have been resolved following tasks: identified functional and structural elements together; the composite index value is represented in a structural formula, the principle of strict deterministic relationship between functional and structural attributes; the choice of averaging of functional and structural attribute.

Methodology. The paper uses traditional methods of mathematical analysis of sets, statistical methods, methods of operations research, generalization, systematization of statistical data, methods of decision theory.

Results. It is proved that without taking into account the structural component, the intrinsic essence of the composite value index cannot be known. The possibility of a comprehensive assessment of the functional and structural organization of a set of cost indices as such is substantiated. It is shown that the organization of the summation will correspond to the state of Pareto - optimality when the estimates of the functional and structural components are equal.

Conclusions. The closer the actual assessment of the organizational complexity of the aggregate to a state of Pareto optimality, more harmonious, more perfect organization together, the qualitatively homogeneous itself the totality and the possibility of its interpretation for practical purposes.

Key words: share index, structure change coefficient, element base diversity, functional and structural organization, group and intergroup relations, Pareto-optimality.

Introduction. A statistical summation is a set of relatively homogeneous elements taken together within specific boundaries of time and space and possessing signs of similarity and difference. A statistical summation has certain properties: indecomposability (a statistical summation is always homogeneous in at least one attribute) and vari- 
ation (quantitative changes in the value of a statistical attribute when one of its elements passes into another). Between the functional and structural components of the organization of the aggregate, the principle of rigid deterministic proportionality operates, reflecting the consistency of the goals of the functional and structural elements of the aggregate with its main goal - the formation of a composite value index.

Assessing the complexity of organizing a composite cost index based on the Pareto-optimality principle makes it possible to determine the proximity of a set of individual cost indices to the optimal state. One of the relative characteristics that take into account the structural changes that have occurred in the aggregate of values is the ratio of the shares of the elements of the aggregate, represented by the formula:

$$
i_{d}=\frac{d_{11}}{d_{00}}=\frac{q_{1} p_{1}}{\sum q_{1} p_{1}} \div \frac{q_{0} p_{0}}{\sum q_{0} p_{0}}=\frac{q_{1} p_{1}}{q_{0} p_{0}} \div \frac{\sum q_{1} p_{1}}{\sum q_{0} p_{0}}=\frac{i_{v}}{l_{v}}
$$

where $d_{11}=\frac{q_{1} p_{1}}{\sum q_{1} p_{1}}-$ the share of the cost of an individual product $\left(q_{1} p_{1}\right)$ in the total cost of the summation $\left(\sum q_{1} p_{1}\right)$ of the current $(« 1 »)$ period;

$d_{00}=\frac{q_{0} p_{0}}{\sum q_{0} p_{0}}-$ share of the cost of the same product $\left(q_{0} p_{0}\right)$ in the total cost summation $\left(\sum q_{0} p_{0}\right)$ on the base $(« 0 »)$ period;

$i_{v}=\frac{q_{1} p_{1}}{q_{0} p_{0}}-$ individual index of the cost of an individual product;

$I_{v}=\frac{\sum q_{1} p_{1}}{\sum q_{0} p_{0}}-$ composite index of the value of the entire summation;

$i_{d}$ - the index of the share (structural changes), which characterizes the relative change in the share of the value of an individual commodity in the aggregate in period " 1 " compared to period " 0 ".

Relation (1) has not found wide application either in statistical theory or in practice due to the fact that the analysis of structural changes using such a simple technique does not provide a comprehensive characteristic of structural changes in the studied summation, does not allow describing the phenomenon as a whole [6, p. 76]. Therefore, when studying structural changes, preference is given to indicators of absolute change in the proportion. Stochastic and vector approaches [4], coefficients of structural shifts by L. Kazinets [1], K. Gatev, A. Salai [2], V. Ryabtsev [3] and others [7] are well-known examples of calculating the absolute change in the proportion.

In our opinion, the methodological potential inherent in formula (1) is much greater than one might imagine. Let's take a closer look at this. Composite index I_v, expressed in terms of fractions of elements of aggregates of value " 0 " of the period $\left(d_{00}\right)$ and «1» of the period $\left(d_{11}\right)$, is defined as follows:

$$
I_{v}=\frac{\sum V_{1 j}}{\sum V_{0 j}}=\frac{V_{11}+V_{12}+\ldots+V_{1 j}+\ldots+V_{1 n}}{\sum V_{0 j}}
$$

Assuming $\frac{v_{1 j}}{v_{0 j}}=i_{v j}$, we find $v_{1 j}=i_{v j} \cdot v_{0 j}$ И $v_{0 j}=\frac{v_{1 j}}{i_{v j}}$

Then

1) $I_{v}=\frac{\sum V_{1 j}}{\sum V_{0 j}}=\frac{i_{v 1} \cdot V_{O 1}+i_{v 2} \cdot V_{O 2}+\ldots+i_{v j} \cdot V_{o j}+\ldots+i_{m n} \cdot V_{o n}}{\sum V_{0 j}}$

But $\frac{V_{o j}}{\sum V_{0 j}}=d_{o j}$

So, $I_{v}=\frac{\sum V_{1 j}}{\sum V_{0 j}}=\sum i_{v j} \cdot d_{o j}$

2) $I_{v}=\frac{\sum V_{1 j}}{\sum V_{0 j}}=\frac{\sum V_{1 j}}{\frac{v_{11}}{i v_{1}}+\frac{V_{12}}{i v_{2}}+\cdots+\frac{v_{1 j}}{i v_{j}}+\cdots+\frac{v_{1 n}}{i v_{\mathrm{n}}}}=$

$=\frac{1}{\frac{V_{11}}{i v_{1} \cdot \sum V_{1 j}}+\frac{V_{12}}{i v_{2} \cdot \sum V_{1 j}}+\cdots+\frac{V_{1 j}}{i v_{j} \cdot \sum V_{1 j}}+\cdots+\frac{V_{1 n}}{i v_{n} \cdot \sum V_{1 j}}}=\frac{1}{\sum \frac{d_{1 j}}{i v_{j}}}$

But $\frac{V_{1 j}}{\sum V_{1 j}}=d_{1 j}$

So, $I_{v}=\frac{\sum V_{1 j}}{\sum V_{0 j}}=\frac{1}{\sum \frac{\mathrm{d}_{1 j}}{i v_{j}}}$

We denote $d_{o j}=d_{00}, d_{1 j}=d_{11}$ and get:

$$
I_{v}=\frac{\sum q_{1} p_{1}}{\sum q_{0} p_{0}}=\sum i_{v} \cdot d_{00}=\frac{1}{\sum \frac{d_{11}}{i_{v}}}
$$

Let us transform formula (2) into a structural formula that shows the change in the "contribution" of individual elements and (or) groups of value aggregates to the formation of the composite index $I_{v}$.

$$
1=\frac{\sum i_{v} \cdot d_{00}}{I_{v}}=\frac{1}{I_{v} \cdot \sum \frac{d_{11}}{i_{v}}}
$$

Since for the aggregates of the value of period " 0 " and period " 1 " the composite index is a constant value, then using formula (1), we can represent formula (3) in the form

$$
S I_{v 00}=\sum \frac{i_{v} \cdot d_{00}}{I_{v}}=\sum i_{d} \cdot d_{00}=\sum d_{11}=\sum \operatorname{contr} d_{00}=1
$$

or 


$$
S I_{v 11}=\sum \frac{l_{v} \cdot d_{11}}{i_{v}}=\sum \frac{d_{11}}{i_{d l}}=\sum d_{00}=\sum \operatorname{contr} d_{11}=1
$$

Formula (4) shows that the structure of the composite index $I_{v}$ in estimates "0" of the period $\left(S I_{v 00}\right)$ is completely determined by the structure of the aggregate of values in the period «1» $\left(\sum d_{11}\right)$.

Formula (5) shows that the structure of the composite index $I_{v}$ in estimates "1" of the period $\left(S I_{v 11}\right)$ absolutely adequate to the structure of the aggregate values in the "0" period $\left(\sum d_{00}\right)$.

Therefore, between changes to the structure of the composite index $I_{v}$ and changes in the structure of the aggregate of values, there is a feedback, namely: if the share of any element of the aggregate of values in the "1" period compared to the " 0 " period changes $n$ times, then the contribution of this element to the formation of the structure of the composite index $I_{v}$ will change in $1 / n$ times.

Based on this, formula (1) can be represented as

From here we find

$$
i_{d}=\frac{d_{11}}{d_{00}}=\frac{\operatorname{contr} d_{00}}{\operatorname{contr} d_{11}}=\frac{i_{v}}{l_{v}}
$$

$$
I_{v}=\frac{i_{v}}{i_{d}}=i_{v} \cdot \frac{\operatorname{contr} d_{11}}{\operatorname{contr} d_{00}}=i_{v} \cdot \alpha_{S}
$$

where $\alpha_{S}=\frac{\operatorname{contr} d_{11}}{\operatorname{contr} d_{00}}$ - structural change ratio of the composite index $I_{v}$, showing the level of difference of the structure of the composite index in the estimates of " 1 " period from the structure of the composite index in the estimates of " 0 " of the period. index.

$$
\text { contr } d_{11}=\frac{I_{v} \cdot d_{11}}{i_{v}}=d_{00} \text { - contribution of an element of a set of values to a structure } S I_{v 11} \text { of a composite cost }
$$

contr $d_{00}=\frac{i_{v} \cdot d_{00}}{I_{v}}=d_{11}$ - contribution of an element of a set of values to a structure $S I_{v 00}$ of a composite cost index.

As a result, we get

$$
I_{v}=\frac{\sum q_{1} p_{1}}{\sum q_{0} p_{0}}=\frac{i_{v j}}{i_{d j}}=i_{v j} \cdot \alpha_{s j}=c
$$

From formula (8) it follows that the composite cost index, represented by modern index theory as a result of dividing the total sums of two sets of values $I_{v}=\frac{\sum q_{1} p_{1}}{\sum q_{0} p_{0}}$, can be defined for any data item of the aggregates or as the quotient of dividing the individual cost index $i_{v}$ on the relative change in the share of this element in the aggregate values $i_{d}$; or as the product of the individual cost index by the coefficient $\alpha_{s}$, characterizing the relative change in the structure of the composite index itself.

Hence, if the share of $j$-element in the aggregate values "1" of the period $\left(d_{11}\right)$ less than its share in the aggregate values " 0 " of the period $\left(d_{00}\right)$, then the significance of this element in the structure of the composite index, expressed in estimates " 1 " of the period (contr $\left.d_{11}\right)$, more than its share in the structure of the composite index, expressed in estimates of "0" period (contr $\left.d_{00}\right)$.

For $d_{11}>d_{00}$ we have an inverse relationship contr $d_{11}<$ contr $d_{00}$.

Thus, formula (8) reflects the principle of rigid deterministic proportionality inherent in any j-element set of cost indices. Principle emphasizing the need to align the goals of the elements of the summation $\left(i_{v j}\right.$ и $\left.i_{d j}\right)$ with its main purpose $\left(I_{v}\right)$, as well as the need for a certain ratio between the parts of the whole $\left(i_{v j} / i_{d j}=i_{v j} \cdot \alpha_{s j}=\right.$ const $)$.

The revealed principle of proportionality allows us to consider the composite value index as a set of interrelated elements, united by the unity of goals and functional integrity. That is, as a system that has all the necessary features: the integrity and segmentation of the object, stable connections between the elements of the system $\left(i_{v j}\right.$ и $\left.i_{d j}\right)$ and integrative qualities inherent in the system as a whole, but not inherent in its elements separately (average values $i_{v j}$ and $\left.i_{d j}\right)[11$, c. $19-21]$.

Then we can talk about the functional and structural organization (organization) of the aggregate of the composite index. Note that it is the issues related to the difference in the levels of the structural and functional organization of the studied systems, the criteria for their selection, consideration of connections, interactions and mutual transitions that occupy a central place in system analysis [11, p. 15].

By functional organization we mean a set of functions and connections between them. The functional organization of the composite index, represented by many individual indices $i_{v}$, reflects the purpose of the system, what it is for. This organization is the most essential characteristic of the system, for the concept of function is closest to the concept of the goal, for the sake of which the system is created.

By structural organization we mean a general idea of the shape, location and number of parts of the system and their interconnections. Structural organization of the composite index, represented by many individual indexes $i_{d}$ and $\alpha_{s}$, characterizes the invariant aspect of the composition of the system and represents the stable ordering of its elements and connections between them.

The functional and structural organization of the system influence each other and are in such a dialectical relationship that it is difficult to establish a one-to-one correspondence between the functions being implemented and the structure of the system. For example, from the standpoint of the structural-functional approach to the creation (analysis) 
of systems existing in the theory of systems, the primacy of the structural aspect of organization is assumed in the sense that in its absence the system disappears. On the other hand, the functional-structural approach, on the contrary, is based on the assumption that the functional purpose of the system is primary in relation to its structural organization [11, p. 49-51].

The authors adhere to the latter point of view: in the relationship between function and structure, the leading role is assigned to the function (functional organization), and the structure (structural organization) is transformed, modified in accordance with the implemented functions, while remaining unchanged (in terms of the composition of the system) in relation to any internal transformations. In this case, the main emphasis, as it should be in the systemic approach, is made on the integrative properties of the object and its integrity; identifying the variety of connections and relationships between individual elements of the object, their group and intergroup relationships.

At least three fundamental properties of this aggregate follow from the principle of proportionality characteristic of the aggregate of the composite value index of any level of the structural and functional organization:

If the composite value index is more (less) than one, then for all members of a given summation, without exception, the individual functional index (value index) will be more (less) than the corresponding individual structural index (share index), that is, at $I_{v}>1$ we always have $i_{v j}>i_{d j}$; at $I_{v}<1$, on the contrary, we have $i_{v j}<i_{d j}$;

1. If in a given set at least one individual functional index of value is greater (less) than the corresponding individual structural index of the share, then this inequality will, without exception, be inherent in the rest of the individual indexes of value and the corresponding individual indexes of the share; as well as the fact that the composite index of the summation will be more (less) than one. That is, if $i_{v j}>i_{d j}$, so $i_{v 1}>i_{d 1}, i_{v 2}>i_{d 2}, \ldots, i_{v n}>i_{d n}$ and $I_{v}>1$. If $i_{v j}<i_{d j}$, so $i_{v 1}<i_{d 1}, i_{v 2}<i_{d 2} \ldots, i_{v n}<i_{d n}$ and $I_{v}<1$

2. If one individual functional value index is greater than the corresponding individual structural share index, for example, $i_{v j}>i_{d j}$, and the other individual functional value index is less than the corresponding individual structural share index, for example, $i_{v k}<i_{d k}$, then these indices belong either to different groups of the same summation and we are dealing with group indices, or the indices belong to different collections.

Consequently, the principle of proportionality inherent in formula (8) makes it possible to "philosophically" perceive the set of value indices as a set of unity (in the form of a composite value index) and diversity (in the form of individual functional value indices and structural share indexes), which are internally and inextricably linked between themselves.

Based on formula (8), we represent the variety of the element base of the set of functional cost indices in the form of a system of equations

$$
\left\{\begin{array}{l}
i_{v 1}=I_{v} \cdot i_{d 1} \\
i_{v 2}=I_{v} \cdot i_{d 2} \\
\ldots \ldots \ldots \ldots \ldots \ldots \\
i_{v n}=I_{v} \cdot i_{d n}
\end{array}\right.
$$

Then the average functional cost index $\overline{C l_{v}}$ for a given summation can be determined by the geometric mean simple formula as

$$
\overline{C l_{v}}=\sqrt[n]{i_{v 1} \cdot i_{v 2} \cdot \ldots \cdot i_{v n}}=I_{v} \cdot \sqrt[n]{i_{d 1} \cdot i_{d 2} \cdot \ldots \cdot i_{d n}}=I_{v} \cdot \overline{\iota_{d}}
$$

where $\overline{i_{d}}=\sqrt[n]{i_{d 1} \cdot i_{d 2} \cdot \ldots \cdot i_{d n}}-$ geometric simple mean of the structural index of the proportion.

Hence we get

$$
I_{v}=\frac{i_{v 1}}{i_{d 1}}=\frac{i_{v 2}}{i_{d 2}}=\cdots=\frac{i_{v n}}{i_{d n}}=\sqrt[n]{\frac{i_{v 1} \cdot i_{v 2} \cdot \ldots i_{v n}}{i_{d 1} \cdot i_{d 2} \cdot \ldots i_{d n}}}=\overline{C l_{v}} / \overline{i_{d}}
$$

Thus, the diversity of the element base of the set of functional value indices and structural share indices is reflected in the presentation of the composite index in the form of a generalizing formula for the geometric mean.

Selecting a geometric mean formula for calculating values $\overline{{C l_{v}}_{v}}, \overline{\boldsymbol{t}_{d}}$ and $I_{v}$ dictated by two fundamental considerations. First, formula (9) can be represented as follows:

$$
I_{v}=\frac{\sum q_{1} p_{1}}{\sum q_{0} p_{0}}=\overline{C l_{v}} / \overline{i_{d}}=\overline{C l_{v}} \cdot \overline{\alpha_{d}}=\text { const }
$$

It is well known from the general theory of statistics that "if, when replacing individual indices with an average value, it is necessary to keep the product of individual values unchanged, then the geometric average should be used" $[5$, p. 77].

Secondly, the calculation methods based on the geometric mean formula reflect a higher stability in relation to errors [4, p. 62].

If we now arbitrarily group the set of functional (individual) cost indices, highlighting in it $k$-th number of groups with $m$ elements in each group, then the summary index of the summation $I_{v}$ can be represented as the geometric mean weighted from the geometric mean group value indices.

For example, we have a set of cost indices, numbering seven elements $(n=7)$. The summation is divided into groups A and B $(k=2)$. Group A consists of two elements $\left(m_{A}=2\right)$. Group B consists of five elements $\left(m_{\mathrm{B}}=5\right)$. Then we get

- composite index of the summation equal to 


$$
I_{v}=\frac{\sum q_{1} p_{1}}{\sum q_{0} p_{0}}=\sqrt[7]{\left(\frac{i_{v 1} \cdot i_{v 2}}{i_{d 1} \cdot i_{d 2}}\right) \cdot\left(\frac{i_{v 3} \cdot i_{v 4} \cdot i_{v 5} \cdot i_{v 6} \cdot i_{v 7}}{i_{d 3} \cdot i_{d 4} \cdot i_{d 5} \cdot i_{d 6} \cdot i_{d 7}}\right)}=\left[\prod_{j=1}^{7} \frac{i_{v j}}{i_{d j}}\right]^{1 / 7}=\overline{c l_{v}} / \overline{\iota_{d}}
$$

- group indices of the summation equal

$$
\begin{gathered}
I_{v}^{A}=\frac{\sum q_{1}^{A} p_{1}^{A}}{\sum q_{0}^{A} p_{0}^{A}}=\sqrt[2]{\frac{i_{v 1} \cdot i_{v 2}}{i_{d 1} \cdot i_{d 2}}}=\left[\prod_{j=1}^{2} \frac{i_{v j}}{i_{d j}}\right]^{1 / 2}=\overline{C l_{v A}} / \overline{\iota_{d A}} \\
I_{v}^{B}=\frac{\sum q_{1}^{B} p_{1}^{B}}{\sum q_{0}^{B} p_{0}^{B}}=\sqrt[5]{\frac{i_{v 3} \cdot i_{v 4} \cdot i_{v 5} \cdot i_{v 6} \cdot i_{v 7}}{i_{d 3} \cdot i_{d 4} \cdot i_{d 5} \cdot i_{d 6} \cdot i_{d 7}}}=\left[\prod_{j=1}^{5} \frac{i_{v j}}{i_{d j}}\right]^{1 / 5}=\overline{C l_{v B}} / \overline{\iota_{d B}}
\end{gathered}
$$

In group indices $I_{v}^{A}$ and $I_{v}^{B}$, along with functional changes in value, intra-group structural changes are also reflected $\left(i_{d \mathrm{~B} \Gamma}=\frac{q_{1} p_{1}}{\sum q_{1}^{\Gamma \mathrm{P}} p_{1}^{\Gamma \mathrm{P}}} \div \frac{q_{0} p_{0}}{\sum q_{0}^{\Gamma_{0}} p_{0}^{\Gamma \mathrm{p}}}=\frac{i_{v}}{l_{V}^{\Gamma \mathrm{p}}}\right)$, occurred in a single group. Intergroup connections and interdependencies naturally arise between groups $\left(i_{d \mathrm{MI}}\right)$, which should be properly considered when calculating $i_{d}$.

Based on the principle of proportionality, it is possible to calculate an individual functional value index, expressed either through a composite index $\left(i_{v}=i_{d} \cdot I_{v}\right)$, either through the group index $\left(i_{v}=i_{d \mathrm{B \Gamma}} \cdot I_{v}^{\mathrm{\Gamma p}}\right)$. Then $i_{v}=i_{d}$. $I_{v}=i_{d \mathrm{B \Gamma}} \cdot I_{v}^{\mathrm{Tp}}$. From this identity we obtain

$$
i_{d} / i_{d \mathrm{B \Gamma}}=I_{v}^{\mathrm{\Gamma p}} / I_{v}=i_{d \mathrm{Mг}}
$$

where $i_{d \mathrm{M \Gamma}}$ - the relative change in the share of the group in the total summation, characterizing intergroup structural changes.

Note that the value $I_{v}^{\mathrm{rp}}=\frac{\sum q_{1}^{\mathrm{rp}} p_{1}^{\mathrm{rp}}}{\sum q_{0}^{\mathrm{rp}} p_{0}^{\mathrm{rp}}}$ may be less (more) one. Then, for this group, the individual functional cost indices $\left(i_{v j}\right)$ there will be fewer (more) individual structural indices $\left(i_{d j}\right)$. Simultaneously for the whole summation $I_{v}$ may be more (less) one, and then in the volume of the entire summation, individual functional indices $\left(i_{v j}\right)$ there will be more (less) individual structural indices $\left(i_{d j}\right)$. Such a change in proportions is precisely due to the actions of intergroup connections.

From expression $i_{d} / i_{d \mathrm{B \Gamma}}=i_{d \mathrm{M \Gamma}}$ define that

Let's represent group indices $I_{v}^{A}$ and $I_{v}^{B}$ as

$$
i_{d}=i_{d \mathrm{B \Gamma}} \cdot i_{d \mathrm{M \Gamma}}=\frac{i_{v}}{l_{v}^{\mathrm{\Gamma p}}} \cdot \frac{I_{v}^{\mathrm{rp}}}{I_{v}}=\frac{i_{v}}{l_{v}}
$$

$$
\begin{gathered}
\left(I_{v}^{A}\right)^{2}=\frac{i_{v 1} \cdot i_{v 2}}{i_{d 1} \cdot i_{d 2}}=\left(\frac{\overline{C l_{v A}}}{\overline{l_{d A}}}\right)^{2} \\
\left(I_{v}^{B}\right)^{5}=\frac{i_{v 3} \cdot i_{v 4} \cdot i_{v 5} \cdot i_{v 6} \cdot i_{v 7}}{i_{d 3} \cdot i_{d 4} \cdot i_{d 5} \cdot i_{d 6} \cdot i_{d 7}}=\left(\frac{\overline{C l_{v B}}}{\overline{\iota_{d B}}}\right)^{5}
\end{gathered}
$$

Then we get the final formula of the composite cost index for the considered example

$$
I_{v}=\left[\prod_{i=1}^{7} \frac{i_{v j}}{i_{d j}}\right]^{1 / 7}=\left[\left(\frac{\overline{\bar{l}_{\overline{ }}}}{\overline{l_{d \mathrm{~A}}}}\right)^{2} \cdot\left(\frac{\overline{c_{v \mathrm{~B}}}}{\overline{l_{d \mathrm{~B}}}}\right)^{5}\right]^{1 / 7},
$$

that is, the formula for the geometric weighted average of the group average cost indices.

In general:

- for non-grouped summations, the composite value index is calculated as the geometric mean simple from the ratios of individual functional value indexes to individual structural indexes of shares

$$
I_{v \Sigma}=\left[\prod_{j=1}^{n} \frac{i_{v j}}{i_{d j}}\right]^{1 / n}=\frac{\overline{c l_{v \Sigma}}}{\overline{l_{d \Sigma}}}
$$

- for grouped summations, the composite value index is calculated as the geometric weighted average of the ratios of the average group functional value indexes to the average group structural indexes of shares

From formulas (12) and (13) it follows that

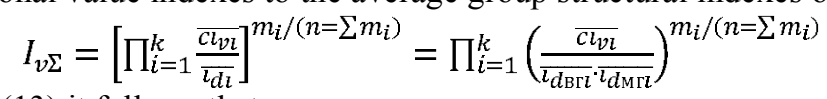

$$
\begin{aligned}
& \overline{C l_{v \Sigma}}=\prod_{i=1}^{k}\left(\overline{C l_{v l}}\right)^{m_{i} /\left(n=\Sigma m_{i}\right)}
\end{aligned}
$$

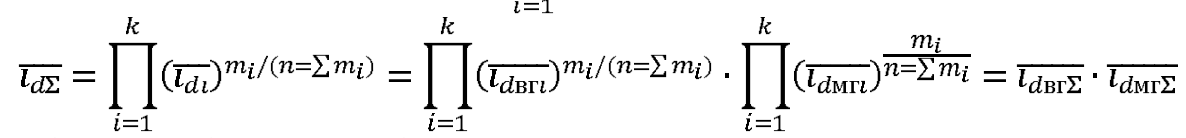

Then formula (13) can be represented as

$$
I_{v \Sigma}=\frac{\overline{C l_{v \Sigma}}}{\overline{l_{d \mathrm{B \Gamma} \Sigma}} \cdot \overline{l_{d \mathrm{M \Gamma} \Sigma}}}=\frac{\overline{I_{v \Sigma}^{\Gamma \mathrm{p}}}}{\overline{l_{d \mathrm{M} \Sigma}}}
$$


where $I_{v \Sigma}^{\mathrm{Tp}}=\frac{\overline{c l_{v \Sigma}}}{\overline{l_{d \mathrm{~B} \Sigma \Sigma}}}-$ the aggregate average group value index.

Like the integral coefficients of Salai and Gatev, formula (13) takes into account the size of the summation $(n)$, the number of selected groups $(k)$, the size of each group $(m)$, the contribution of each group to the formation of the studied trait $\frac{m}{n=\sum m}$.

But unlike the coefficients of Salai, Gatev and others, which do not link structural differences with the final result, the indicator of the average share $\left(\overline{\boldsymbol{l}_{d}}\right)$ together with the functional average cost index $\left(\overline{C l_{v}}\right)$ in formula (13) allow us to determine the generalized level of influence of each of these two factors on the change in the final result, represented by the composite cost index $\left(I_{v}\right)$.

According to the authors, formulas (12) and (13) are as important as the formula $I_{v}=I_{q} \cdot I_{p}$, expressing in modern index theory the conceptual principle of factor reversibility, according to which the product of a given index of quantities $\left(I_{q}\right)$ and the original price index $\left(I_{p}\right)$ should be equal to the change in value $\left(I_{v}\right)$ considered unit $[8, \mathrm{p} .10]$.

This statement, firstly, is based on the law of classical logic of Aristotle: the own essence (essence) of a phenomenon is inversely proportional to the volume of the concept of this phenomenon [9, p.113-115], that is $H=J \cdot \frac{1}{n}$

where $H$ - the logical essence of a set, which characterizes classes of objects or properties that are homogeneous in a certain respect and is a semantic synthesis of the laws of logic, the rules for the functioning of a set and its elements that form the functional of the existence of a set;

$-J$ is a measure of the element base of the aggregate reflected in the consciousness, characterizing the number of its elements of interest to the researcher from the point of view of the research goal;

$-n$ is the volume of the concept of the summation (the number of elements in the summation).

Hence it follows if $J=m, n=\sum m$, so $H=\frac{m}{\sum m}=d$, where $d$ - the share of an element or a group of elements in the total volume of the summation that interests the researcher. This means that without taking into account the structural component, the intrinsic essence of the aggregate of the composite value index cannot be cognized.

Second, the importance of taking structural changes into account in the decomposition of the composite value index lies not only in determining the contribution of the factor $i_{d}$ in the formation of a consolidated cost index $I_{v}$, but also in the possibility of a comprehensive assessment of the functional and structural organization of the aggregate of the composite value index as such.

The point is that for $I_{v}=$ const, according to formula (8) represented by the expression $I_{v}=i_{v j} \cdot \alpha_{s j}$, the growth of one of the factors as a result of any changes in period " 1 " in comparison with period " 0 " is compensated by an equivalent decrease in the other factor. Let's represent the value of the pivot index $I_{v}=i_{v 1} \cdot \alpha_{s 1}=i_{v 2} \cdot \alpha_{S 2}=\cdots=$ $i_{v n} \cdot \alpha_{s n}$ as a set $I_{v}=\left\{I_{v 1}, I_{v 2}, I_{v 3} \ldots\right\}$, consists of dotes $I_{v j}\left(\alpha_{s j} ; i_{v j}\right)$.

This set can be considered as a Pareto set [12, p.120-121], that is, as a set of equally preferred options for achieving a result by various combinations of factors, in which an increase (decrease) in one coordinate, for example, $\alpha_{s j}$ (as abscissas) entails decreasing (increasing) another coordinate $i_{v}$ (as ordinates) without changing the final result результата $I_{v}$.

On the flat $\alpha_{s} 0 i_{v}$ a set $I_{v}=$ const, according to [10, p.75], it is visualized as a graph of an isosceles hyperbola. This graph at the point $I_{v j}\left(\alpha_{s j} ; i_{v j}\right)$ of a set $I_{v}=\left\{I_{v 1}, I_{v 2}, I_{v 3} \ldots\right\}$ is intersected by a ray $r_{j}$, originating from the origin and representing a given diameter of the hyperbola. The beam is characterized by an attituder $r_{j}=i_{v j} / \alpha_{s j}$, which sets the angle of inclination of the beam to the axes $0 \alpha_{s}$ and $0 i_{v}$ and is the vector of the gradient of the steepest increase of the function $I_{v}=f\left(\alpha_{s j} ; i_{v j}\right)$.

Among many rays $r=\left\{r_{1}, r_{2}, r_{3} \ldots\right\}$ there is one single ray in which the value of one of the factors cannot be "improved" without "worsening" the other. The point of intersection of such a ray with the set $I_{v}=$ const will characterize the state of Pareto optimality.

Obviously, such a state is possible if and only if the straight line $i_{v}=\alpha_{s}$ is the direction of the global extremum of the function $I_{v}=f\left(\alpha_{s j} ; i_{v j}\right)$. The direction in which $I_{v}=i_{v} \cdot \alpha_{s}=i_{v}{ }^{2}=\alpha_{s}{ }^{2}=\max$, or when a $i_{v} / \alpha_{s}=r=$ 1 (fig. 1).

$$
i_{v} \quad r=1
$$




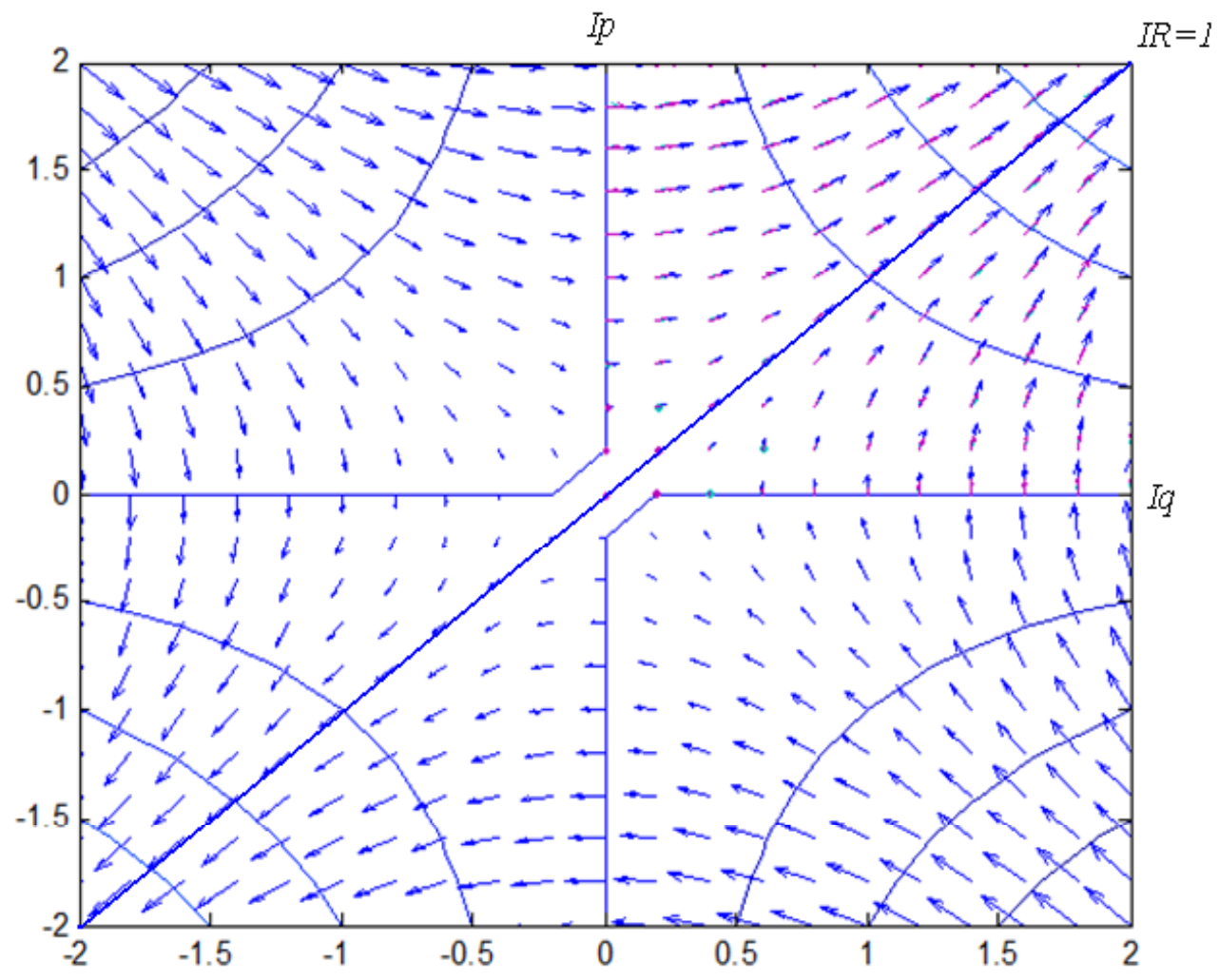

Fig. 1. Field of gradients of the spatial function $I_{v}=f\left(\alpha_{s j} ; i_{v j}\right)$.

This is indeed so due to the fact that $i_{v}$ and $\alpha_{s}$ - the essence of different combinations of the same initial values $\left\{q_{0}, q_{1}, p_{0}, p_{1}\right\}$, and also due to the fact that $i_{v}$ and $\alpha_{S}$-dimensionless relative quantities that have the same scale of calculation.

Any deviation from the ray $r=1$, for example, right and down leads to growth $\alpha_{S}$ and decrease $i_{v}$. Conversely, the deviation to the left and upward from the ray $r=1$ causes a decrease in $\alpha_{S}$ and an increase in $i_{v}$.

It happens that the transition from one point of the set $I_{v}=\left\{I_{v 1}, I_{v 2}, I_{v 3} \ldots\right\}$ to the other it allows one to "improve" one factor without "worsening" the other. In this case, the transition leads to an improvement in the Pareto situation (see point $I_{v 2}{ }^{*}$ on fig. 2). 


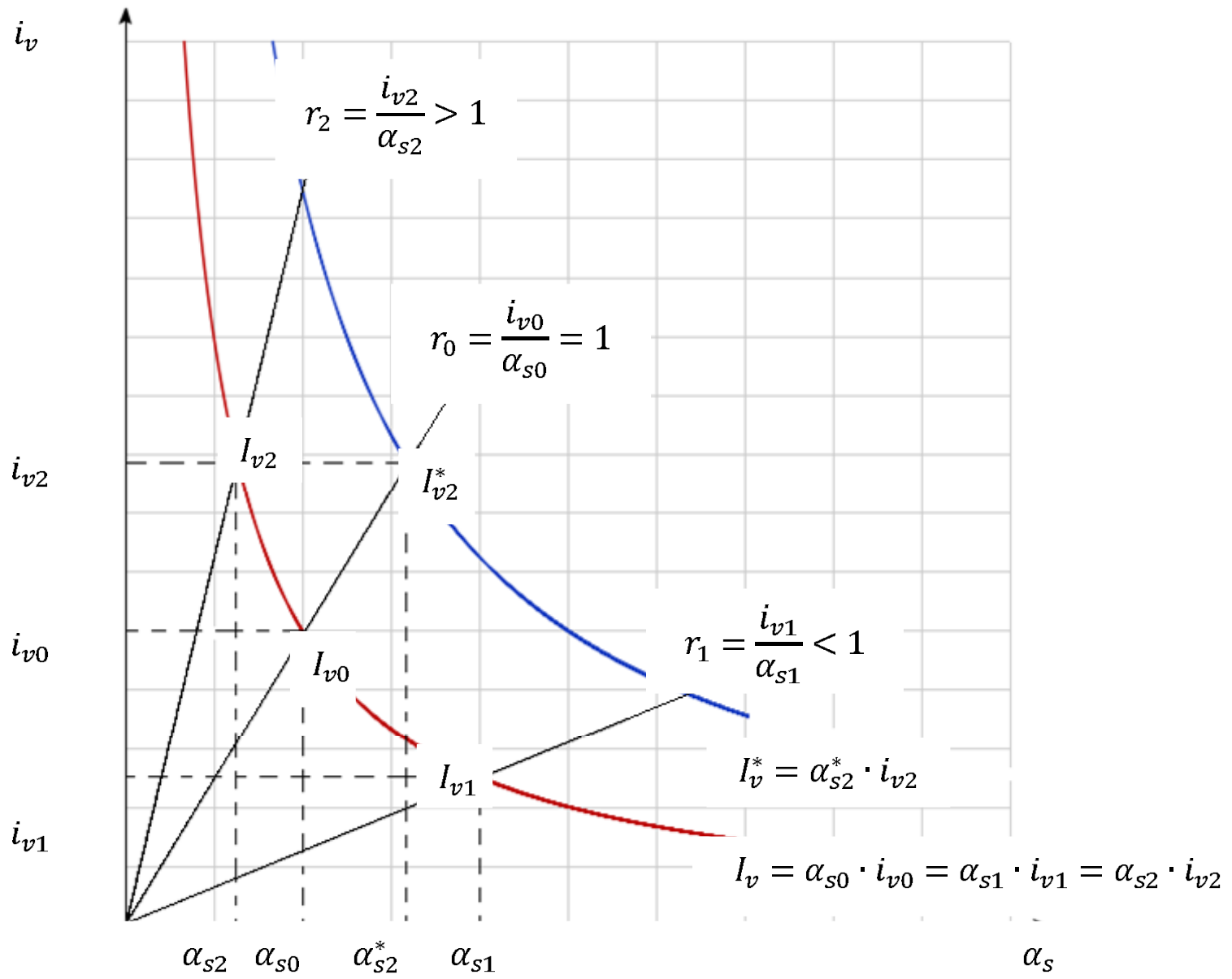

Fig. 2. Change in the state of Pareto optimality

Therefore, if $I_{v}=\overline{\tau_{v}} \cdot \overline{\alpha_{S}}={\overline{t_{v}}}^{2}={\overline{\alpha_{S}}}^{2}$, then the state of Pareto optimality has been reached for the entire aggregate of the composite cost index. In other words, we can say that a necessary condition for achieving the Pareto optimality situation is the condition according to which $\sqrt{I_{v}}=\overline{c l_{v}}=\overline{\alpha_{S}}$.

A sufficient condition for achieving Pareto optimality is a situation in which $r=\frac{\overline{c_{v}}}{\overline{\alpha_{S}}}=1$.

From an information and content point of view, the meaning of the indicator $r$, expressed through the ratio of the means $\bar{r}=\frac{\overline{c_{w_{v}}}}{\overline{\alpha_{S}}}$ in accordance with [9, p.120] is as follows. This relationship is represented in the form $r=\frac{\overline{c_{v}}}{\overline{\alpha_{S}}}=$ $\overline{C l_{v}} / \frac{1}{i_{d}}=\overline{C l_{v}} \cdot \overline{C l_{v}} /_{I_{v}}$, is a pragmatic essence $(r)$ of a summation of composite value indices, defined by the product of the sensuous entity about the means to an end $\left(\overline{c l_{v}}\right)$ and the logical entity about the means of achieving the goal per unit of information about the main goal, the result $\left(\overline{C l_{v}} / I_{v}\right)$. Then the attitude $r=\frac{\overline{c l_{v}}}{\overline{\alpha_{S}}}$ can be interpreted as an integral assessment of the functional $\overline{C h_{\nu}}$ and structural $\overline{\alpha_{S}}$ the complexity of the aggregate of the composite cost index, or as an estimate of the organizational complexity of the aggregate.

If the assessment of the organizational complexity of the composite cost index summation is greater than one, that is $r>1$, then in the aggregate, the functional organization prevails over the structural organization. I., respectively, if the assessment of organizational complexity is expressed by the inequality $r<1$, then the structural organization of the aggregate of the composite value index dominates over the functional organization.

It may seem that from the standpoint of the functional and structural approach, it is preferable when $r>1$, that is, when function dominates structure. However, it is not. As can be clearly seen in Fig. 1, the field of gradients of the spatial function $I_{v}=f\left(\alpha_{s j} ; i_{v j}\right)$ tends towards the point [11], at which the global extremum of this function is reached.

This implies that if the assessment of the organizational complexity of the summation is equal to one, that is $r=1$, then the aggregate of the composite value index has Pareto-optimality and cannot be improved in this state.

Thus, it can be argued that the condition $r=1$ is that normalized-preferable condition with which the actual values of the assessment of the organizational complexity of the summation should be compared. The closer the actual values $r_{\text {факт }}$ to the normalized value $r_{\mathrm{H}}=1$, the closer the functional and structural organization of the aggregate of the composite value index is to the state of Pareto optimality. 


\section{ЛИТЕРА ТУРА}

1. Казинец Л.С. Темпы роста и структурные сдвиги в экономике (Показатели планирования и анализа).- М.: Экономика, 1981.- $184 \mathrm{c}$.

2. Социальная статистика: учебник; под ред. И.И. Елисеевой.- М.: Финансы и статистика, 2002.- 480 с.

3. Заварова Е.В., Чудилин Г.А. Региональная статистика: учебник.- М.: Финансы и статистика, 2006.- 624 с.

4. Бессонов В.А. Проблемы анализа российской макроэкономической динамики переходного периода.- М.: ИЭПІ, 2005.-244 c.

5. Общая теория статистики: Учебник/ под ред. Чл.-корр. РАІ И.И. Елисеевой.- М.: Финансы и статистика, 1995.$368 \mathrm{c}$.

6. Перстенёва Н.П. Методология статистического исследования структурно-динамических изменений (на примере экономики Самарской области): диссертация канд. эконом. наук.- Самара, 2003.- $141 \mathrm{c.}$

7. Перстенёва Н.П. Критерии классификации показателей структурных различий и сдвигов. - Журнал Фундаментальные исследования.- 2012.-№3 (часть 2) - с. 478-482.

8. Руководство по индексу потребительских цен: теория и практика.- Издание на русском языке МОТ/МВФ/ОЭСР/Евростат/ЕЭК ООІ/Всемирный банк, Вашингтон, Международный Валютный Фонд, 2007.- 679 с.

9. Системный анализ в экономике и организации производства: Учебник для студентов, обучающихся по специальности «Экономическая информатика и АСУ»/ С.А. Валуев, Н.В. Волкова, А.П. Градов и др.; Под общ. ред. С.А. Валуева, Н.В. Волковой.- Л.: Политехника, 1991.- 398с.: и.л.

10. Курицын A.B., Сологубов С.В. Средняя геометрическая как аб̆солютный максимум аналитической функции индекса стоимости.- Статистика в современном мире: методы, модели, инструменты: материалы IV Международной HITK/ Ростовский государственный экономический университет (РИНХ) - Ростов н/Д: ИПК РГЭУ (РИНХ) 2016.- 444c.

11. Заболеева-Зотова А.В. Основы системного анализа: Учебное пособие/ С.А.Фоменков, Ю.А. Орлова Волгоград ИУІЛ. - Изд. ВолгГТУ, 2012.-230С.

12. Евланов Л.Г. Теория и практика принятия решений / Редкол.: Е.М. Сергеев и др.- М.: Экономика, 1984г. - $176 \mathrm{c}$.

\section{REFERENCES} 1981.- $184 \mathrm{~s}$.

1. Kazinets L.S. Tempy rosta i strukturnye sdvigi v ehkonomike (Pokazateli planirovaniya i analiza).- M.: Ehkonomika,

2. Sotsial'naya statistika: uchebnik; pod red. I.I. Eliseevoi.- M.: Finansy i statistika, 2002.- $480 \mathrm{~s}$.

3. Zavarova E.V., Chudilin G.A. Regional'naya statistika: uchebnik.- M.: Finansy i statistika, 2006.- 624 s. 2005.-244 s.

4. Bessonov V.A. Problemy analiza rossiiskoi makroehkonomicheskoi dinamiki perekhodnogo perioda.- M.: IEHPP,

5. Obshchaya teoriya statistiki: Uchebnik/ pod red. Chl.-korr. RAN I.I. Eliseevoi.- M.: Finansy i statistika, 1995.- 368 s.

6. Persteneva N.P. Metodologiya statisticheskogo issledovaniya strukturno-dinamicheskikh izmenenii (na primere ehkonomiki Samarskoi oblasti): dissertatsiya kand. ehkonom. nauk.- Samara, 2003.- $141 \mathrm{~s}$.

7. Persteneva N.P. Kriterii klassifikatsii pokazatelei strukturnykh razlichii i sdvigov. - Zhurnal Fundamental'nye issledovaniya.- 2012.-№3 (chast' 2) - s. 478-482.

8. Rukovodstvo po indeksu potrebitel'skikh tsen: teoriya $i$ praktika.- Izdanie na russkom yazyke MOT/MVF/OEHSR/Evrostat/EEHK OON/Vsemirnyi bank, Vashington, Mezhdunarodnyi Valyutnyi Fond, 2007.- 679 s.

9. Sistemnyi analiz v ehkonomike i organizatsii proizvodstva: Uchebnik dlya studentov, obuchayushchikhsya po spetsial'nosti «Ehkonomicheskaya informatika i ASU»/S.A. Valuev, N.V. Volkova, A.P. Gradov i dr.; Pod obshch. Red. S.A. Valueva, N.V. Volkovoi.- L.: Politekhnika, 1991.- 398 s.: il.

10. Kuritsyn A.V., Sologubov S.V. Srednyaya geometricheskaya kak absolyutnyi maksimum analiticheskoi funktsii indeksa stoimosti.- Statistika v sovremennom mire: metody, modeli, instrumenty: materialy IV Mezhdunarodnoi NPK/ Rostovskii gosudarstvennyi ehkonomicheskii universitet (RINKh) - Rostov n/D: IPK RGEHU (RINKh) 2016.- $444 \mathrm{~s}$.

11. Zaboleeva-Zotova A.V. Osnovy sistemnogo analiza: Uchebnoe posobie/ S.A. Fomenkov, Yu.A. Orlova - Volgograd IUNL. - Izd. VolGGTU, 2012.-230S.

12. Evlanov L.G. Teoriya i praktika prinyatiya reshenii / Redkol.: E.M. Sergeev i dr.- M.: Ehkonomika, 1984g. - 176 s.

\section{OБ ABTOPAX | ABOUT AUTHORS}

Курицын Анатолий Васильсвич, Директор представительства ФГБОУ ВО «РГЭУ (РИНХ)», в г.Георгиевске Ставропольского края, кандидат экономических наук, доцент, 357831, г. Георгиевск Ставропольского края, ул.Кочубея, 30, Email: filialrgeu@yandex.ru Kuritsyn Anatoly Vasilyevich, Director of the Representative Office of the FSUE of HE «RSUU (RINH)» in Georgievsk, Stavropol Territory,Candidate of Sciences in Economics, Associate Professor, 357831, Georgievsk, Stavropol Territory, Kochubei St., 30, Email: filialrgeu@yandex.ru

Румпшева Ашша Юрьевна, Директор института международных программ, кандидат экономических наук, доцент, 190103, Санкт-Петербург, Лермонтовский пр., д. 44, Email: post_graduate@mail.ru Rumyantseva Anna, Head of the Institute of International Programs, PhD, associate professor, 190103, St. Petersburg, Lermontovsky Prospect, 44, Email: post_graduate@mail.ru

Лазарева Наталья Алексеевна, Доцент кафедры международных финансов, и бухгалтерского учета, кандидат экономических наук, доцент, 190103, Санкт-Петербург, Лермонтовский пр., д. 44,

Email: nataly.lazarev.1972@mail.ru 

accounting,

Lazareva Natalia Alekseevna, Associate Professor at the Department of International Finance, and Candidate of Sciences in Economics, associate professor, 190103, St. Petersburg, Lermontovsky Prospect, 44, Email: nataly.lazarev.1972@mail.ru

Дата поступления в редакцию: 12.06.2019

После рсцензирования: 23.02.2020

Дата принятия к публикации: 23.05.2020 